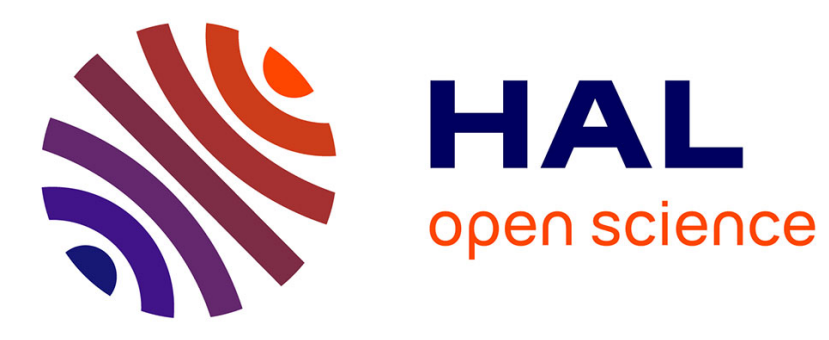

\title{
The perinatal health of immigrant women in France: a nationally representative study
}

Fabienne El-Khoury Lesueur, Anne-Laure Sutter-Dallay, Lidia Panico, Elie Azria, Judith van Der Waerden, Nolwenn Regnault Vauvillier, Marie-Aline Charles, Maria Melchior

\section{To cite this version:}

Fabienne El-Khoury Lesueur, Anne-Laure Sutter-Dallay, Lidia Panico, Elie Azria, Judith van Der Waerden, et al.. The perinatal health of immigrant women in France: a nationally representative study. International Journal of Public Health, 2018, 63 (9), pp.1027-1036. 10.1007/s00038-018-1146y . hal-01977884

\section{HAL Id: hal-01977884 https://hal.sorbonne-universite.fr/hal-01977884}

Submitted on 29 Jun 2020

HAL is a multi-disciplinary open access archive for the deposit and dissemination of scientific research documents, whether they are published or not. The documents may come from teaching and research institutions in France or abroad, or from public or private research centers.
L'archive ouverte pluridisciplinaire HAL, est destinée au dépôt et à la diffusion de documents scientifiques de niveau recherche, publiés ou non, émanant des établissements d'enseignement et de recherche français ou étrangers, des laboratoires publics ou privés. 


\section{The Perinatal Health of Immigrant Women in France: A Nationally Representative Study}

Fabienne El-Khoury Lesueur 1 , Anne-Laure Sutter-Dallay 23 , Lidia Panico 4 , Elie Azria 56 , Judith Van der Waerden 7 , Nolwenn Regnault Vauvillier 8 , Marie-Aline Charles 9 , Maria Melchior 7

\section{Affiliations}

1 Department of Social Epidemiology, Institut Pierre Louis d'Epidémiologie et de Santé Publique IPLESP, INSERM, Sorbonne Université, Paris, France. fabienne.khoury@inserm.fr.

2 University of Bordeaux, 33000, Bordeaux, France.

3 Team Pharmacoepidemiology, Bordeaux Population Health Research Center, University of Bordeaux, Inserm, UMR 1219, 33000, Bordeaux, France.

$4 \quad$ French Institute for Demographic Studies (INED), Paris, France.

5 Obstetrical, Perinatal and Pediatric Epidemiology Team (EPOPé), Epidemiology and Biostatistics Sorbonne Paris Cité Center, INSERM, UMR 1153, DHU Risk in Pregnancy, Paris, France.

6 Department of Obstetrics, Groupe Hospitalier Paris Saint Joseph, Paris Descartes University, Paris, France.

7 Department of Social Epidemiology, Institut Pierre Louis d'Epidémiologie et de Santé Publique IPLESP, INSERM, Sorbonne Université, Paris, France.

8 Department of Non-communicable Diseases and Trauma, Santé Publique France, Saint-Maurice, France.

9 Early ORigin of the Child's Health and Development Team (ORCHAD), Epidemiology and Biostatistics Sorbonne Paris Cité Center (CRESS), INSERM, UMR1153, Paris Descartes University, France, 75014, Paris, France. 


\section{ABSTRACT}

\section{Objective}

Despite the healthy migrant effect, immigrants and descendants of immigrants face health challenges and socio-economic difficulties. We examine the health of women of migrant origin during the perinatal period.

\section{Methods}

Data come from approximately 18,000 women participating in the nation-wide French ELFE (Etude Longitudinale Française Depuis l'Enfance) study. We studied pre-pregnancy BMI, gestational diabetes mellitus (GDM), as well as tobacco, and alcohol consumption during pregnancy according to migrant status and region of origin.

\section{Results}

Women from North-Africa and Turkey had a higher risk of pre-pregnancy overweight and GDM, while women from Eastern Europe and Asia had a lower risk of pre-pregnancy overweight and obesity, but a higher risk of GDM compared to non-immigrants. Women from Sub-Saharan Africa had a higher risk of being overweight or obese pre-pregnancy. Compared to non-immigrants, immigrants -but not descendants of immigrants- had lower levels of tobacco smoking, while descendants of immigrants were less likely to drink alcohol during pregnancy.

\section{Conclusions}

Women of migrant origin have some healthier perinatal behaviour compared to non-immigrants, but some groups are at risk of overweight and having GDM.

\section{Keywords}

Migrant; women; maternal health; pregnancy; overweight; obesity; gestational diabetes mellitus; smoking; alcohol.

\section{INTRODUCTION}

Western European countries' populations comprise a considerable and growing proportion of immigrants and descendants of immigrants (OECD and UN-DESA 2013) with a sizeable proportion of births to foreign-born women (Europ-Peristat 2013). Immigrants to Europe face particular challenges, particularly in terms of socio-economic conditions since they tend to have higher rates of unemployment and work in occupations that are less advantaged than natives (OECD 2014). This disadvantage persists to Europe-born children of immigrants (OECD Centre for Opportunity and Equality 2017) and influences the health status of both generations (Rechel 2011; Missinne and Bracke 2012; Almeida et al. 2013). Immigrants are also generally younger than non-immigrants (Eurostat 2017), with an increasing share of women (Kulu and González-Ferrer 2014; Kulu et al. 2017). 
To date, European data on the health of immigrants and their descendants is incomplete and shows contradictory results. On the one hand immigrants benefit from the reported 'healthy migrant effect' (Almeida et al. 2013), whereby individuals who are able to migrate are healthier than their non-migrating counterparts, or non-immigrants. At the same time, because of hardship experienced during migration and in the country of arrival, as well as difficulties in access to health care and low health literacy (DAVIES et al. 2009), immigrants have elevated levels of various health problems (Rechel et al. 2013). These mixed results are also observed in France: while early work showed that immigrants have an advantage in terms of mortality, more recent work indicates elevated levels of mortality, perceived health and psychological difficulties among immigrants (Guardia et al.; Moullan and Jusot 2014; Khlat and Guillot 2017). A reason for mixed results in the literature is that some studies pool heterogeneous groups - this is the case of studies that examine the health of 'ethnic minorities', pooling immigrants and their descendants together (Falah-Hassani et al. 2015). Yet immigrant populations are varied not only in terms of geographic region of origin or ethnicity but also in terms of their migration history; therefore identifying populations at risk of perinatal health problems entails distinguishing specific subgroups.

Research shows that compared to non-immigrant women, immigrants who are pregnant tend to have healthier behaviours (e.g. tobacco and alcohol use) but worse physical health (e.g. BMI, gestational diabetes) and higher maternal mortality (Gagnon et al. 2011; Saurel-Cubizolles et al. 2012; Delavari et al. 2013; Melchior et al. 2015; Mårdby et al. 2017). Yet to our knowledge, past studies have rarely examined women's region of origin and studied the health of descendants of immigrants. Pre-pregnancy BMI, gestational diabetes mellitus (GDM), alcohol and tobacco consumption are associated with adverse maternal, neonatal, and childhood health outcomes (Metzger 2007; Agrawal et al. 2010; Williams et al. 2015) that could be either prevented or treated in the case of GDM (Crowther et al. 2005). In the present study, we test the association between women's immigrant status, their region of origin, and these maternal health behaviours and indicators using data from the French nationally representative ELFE birth cohort study. Our objective is to examine whether, after adjusting to several potential confounders, immigrants and descendants of immigrants benefit from a healthy migrant effect or are disadvantaged in terms of health outcomes and behaviours compared to non-immigrants.

\section{METHODS}

\section{Study design and setting}

ELFE (Etude Longitudinale Française depuis l'Enfance) is an ongoing longitudinal nationwide French birth cohort study. A total of 18,041 mothers and their infants born in $2011(\mathrm{n}=18,329)$ were initially recruited using random sampling in 320 maternity wards throughout mainland France (51\% participation rate).(Vandentorren et al. 2009) Women of at least 18 
years of age, planning to stay in metropolitan France in the following three years, and capable of giving informed consent in one of the study languages (French, English, Arabic, and Turkish) were included. Fifty-two women withdrew from the study, leaving a sample of 17,988 participants studied in all analyses.

\section{Data source}

At the time when women delivered, data were collected by trained midwifes via standardised face-to-face interviews at the maternity; additionally participants also completed a self-reported questionnaire on their health and health-related behaviours (e.g. smoking during pregnancy, alcohol use). Data regarding maternal gestational diabetes and birth characteristics were extracted directly from medical records. Information collected included women's sociodemographic, behavioural and medical characteristics such as age, income, region of origin, socio-professional status, pre-pregnancy body weight and height, and gestational diabetes. Partner's smoking and support during pregnancy was collected at 2 months post-partum via telephone interview by trained investigators in French or any other language requested by the participants at recruitment (response rate $=86.4 \%$ ).

\section{Study outcomes}

Women's pre-pregnancy BMI (collected via medical record) was categorised into four categories (underweight, overweight, obese vs. normal). GDM was considered as diagnosed by the local health care unit (yes vs. no). Smoking status prior to pregnancy and in the last trimester of pregnancy was collected and classified into three categories (smokers, quitters during pregnancy, vs. non-smokers). Alcohol use during pregnancy was classified as follows: $<1$ drink per month, $\geq 1$ drink per month vs. none.

\section{Mother's immigrant status}

Women were asked about their citizenship and birthplace, as well as those of their parents. This information was used to identify 'immigrant status' using the definition established by the French Institute for Demographic studies (INED) : (Beauchemin et al. 2015) "non-immigrants": women born to two French-born parents, "descendants of immigrants": women born in France with at least one immigrant parent, and "immigrants": women not born in France, and without French citizenship at birth.

\section{Region of origin}

Women's geographical region of origin was defined as the region of birth for immigrant women, and parents' region of birth for descendant of immigrants (North Africa or Turkey, Sub-Saharan Africa, Eastern Europe and Asia, Other region vs. Metropolitan France/ European Union). Among descendants of immigrants, in case of discordance between maternal and paternal region of birth ( $5 \%$ of the cases), we used maternal region of birth. Non-immigrants' region of origin was set as 'France/EU'. 


\section{Covariates}

Several factors potentially associated with immigrant status or the studied outcomes, assessed during the birth interview, except for the partner's smoking status collected at two months post-partum via telephone, were included as potential covariates.

These included: demographic characteristics: maternal age, number of children including the ELFE child and residential area; social and economic circumstances: maternal educational level, the highest of maternal or paternal occupational grade, maternal employment status; partner characteristics: smoking status, employment status at the time of pregnancy, and educational level; pregnancy characteristics: unplanned pregnancy, and sufficient partner support during pregnancy. Health outcomes such as tobacco use and BMI before pregnancy were also considered as covariates in some analysis when appropriate. All multivariate analysis were also adjusted for recruitment wave.

\section{Statistical Analyses}

Missing data on covariates were imputed using multiple imputations by chained equations under fully conditional specification and assuming missingness at random. Bivariate binomial and multinomial logistic regression models were implemented to identify factors potentially associated with study outcomes. All factors potentially associated with the outcome under study in bivariate analyses $(p<0.20)$ were included in the multivariate models. Multivariate logistic regression models were implemented with a random intercept corresponding to the maternity ward, and adjusting for the study data collection wave (four waves: April; June-July; September-October; November-December). All participants with complete outcome data were included in the multivariate analyses. The non-immigrant population was considered as the reference group in all analyses. We also conducted a sensitivity analysis including the duration of stay in France (>10 years, vs. $<10$ years) to test for an acculturation effect.

All analyses were performed with SAS, version 9.4. Statistical analyses were conducted separately on each of the ten imputed datasets and the results (OR, CI 95\%) were pooled using 'PROC MIANALYZE'.

\section{RESULTS}

Table 1 presents descriptive characteristics of women included in the analysis. [Table I1 near here]

Out of 17,988 women included in the analyses, $68.4 \%$ were non-immigrant $(n=12,294), 11.1 \%$ were immigrants $(n=2,000)$, and $12.1 \%$ were descendant of immigrants $(n=2,179)$. Immigrant status was missing for $8.4 \%$ of study women $(n=1,515)$.

As shown in Table 2, the majority of immigrants in this sample came from North Africa or Turkey (62.8\%); among descendants of immigrants a majority come from a country of the European Union other than France (53.2\%). [Table II near here]

Regarding pre-pregnancy BMI; 7.9\% of women were underweight, $64.9 \%$ had normal BMI, $17.2 \%$ were overweight and $10 \%$ were obese $(\mathrm{n}=17,623)$, while $7.5 \%$ of women had GDM $(\mathrm{n}=17,045)$. 
More than half of women included in the study (57.6\%) did not smoke prior to pregnancy, around half of pre-pregnancy smokers stopped smoking during pregnancy $(22.6 \%)$ while $19.8 \%$ continued smoking $(n=17,746)$. The majority of women (81.9\%) did not drink alcohol during pregnancy, $13.5 \%$ drank less than one drink a month, and $3.7 \%$ drank more than one drink per month $(\mathrm{n}=17,838)$. 


\section{Results of multivariate analyses}

\section{BMI and GDM (table 3)}

Maternal region of origin rather than immigrant status was associated with pre-pregnancy BMI and GDM. Compared to non-immigrants, women from Sub-Saharan Africa were more likely to be overweight $(\mathrm{OR}=1.37(95 \% \mathrm{CI}, 1.06-1.77))$ or obese $(\mathrm{OR}=1.58(95 \% \mathrm{CI}, 1.14-2.18))$, those from North Africa or Turkey had a higher likelihood of being overweight $(\mathrm{OR}=1.39(95 \% \mathrm{CI}, 1.13$ - 1.71)), whereas women from Eastern Europe and Asia were less likely to be overweight $(\mathrm{OR}=0.59(95 \% \mathrm{CI}, 0.39-0.88))$, and obese $(\mathrm{OR}=0.35(95 \% \mathrm{CI}, 0.18-0.69))$. Women from North Africa or Turkey $(\mathrm{OR}=2.00(95 \% \mathrm{CI}, 1.27$ - 3.16)), as well as those from Eastern Europe or Asia (OR=1.68 (95\% CI, 1.25 - 2.25)) were more likely to have GDM compared to non-immigrant women. In complementary analysis, adjusting for the duration of stay in France did not change the direction or statistical significance of the reported associations (supplementary table S1).

[Table 3 near here]

\section{Tobacco and alcohol consumption (table 4)}

Immigrant women were less likely to smoke tobacco before and during pregnancy than non-immigrants, whereas descendants of immigrants had comparable smoking levels. Women from North Africa or Turkey, Sub-Saharan Africa and other countries were least likely to smoke during pregnancy. In terms of alcohol use, immigrant mothers had comparable levels to non-immigrants. Descendants of immigrants were less likely to drink less than one drink of alcohol per month compared to non-immigrants, but had comparable rates of drinking more than one alcoholic drink per month. Women from North Africa or Turkey were significantly less likely to drink alcohol than non-immigrants. These associations were not modified after adjusting for the duration of stay in France (supplementary table S2). [Table 4 near here]

\section{DISCUSSION}

\section{Key results}

In a nationwide study of women giving birth in France in 2011, we found that the region of origin, and not the immigrant status, was associated with BMI and GDM. The region was also associated with alcohol and tobacco use during pregnancy regardless of immigrant status. While immigrant women were less likely to smoke during pregnancy. These results indicate that immigrant status and the region of origin should be taken into account by health professionals aiming to prevent and address risk factors of poor pregnancy outcomes such as BMI and GDM. Given the high proportion of children born to women who are immigrant or descend from immigrants in France, as in many other European countries, addressing their health needs should be a priority.

\section{Interpretation}

\section{BMI and GDM}

Explanations of higher rates of overweight and GDM among immigrants include nutritional factors, the experience of stress, discrimination and differences in screening rates compared to non-immigrants. First, according to the developmental 
origins of health and disease theory, early childhood metabolic programming (Barker 2012); nutritional deficiencies in foetal and early life could partly explain the higher likelihood of metabolic disorders. However our results do not fully agree with this explanation since descendants of immigrants born in France who are less likely to be exposed to early nutritional deprivation, had the same rates of GDM as immigrants. Second, the change in lifestyle habits previously documented among immigrants living in Europe, with the replacement of some healthier "native" diets by the Western diet and an increase in the consumption of energy-dense foods, could also play a role(Gilbert and Khokhar 2008). Third, stress resulting from the experience of hardship as well as different forms of discrimination linked to a history of immigration could also explain unhealthy behaviours and an increase the prevalence of high BMI and GDM (McEwen and Gianaros 2010). The region of origin, essentially a proxy for ethnicity (Gagnon et al. 2010), is in this case a more precise indicator of discrimination and associated stress than immigrant status (Missinne and Bracke 2012). Importantly, our analyses accounted for multiple measures of socioeconomic position, implying that immigrant status and the region of origin influence health during the perinatal period above and beyond socioeconomic circumstances. Finally, the elevated likelihood of GDM among women of North African or Asian, but not Sub-Saharan descent, goes against findings produced by other studies (Gagnon et al. 2011). It could be that women of Sub-Saharan African descent are under-diagnosed, since in France screening of GDM is not universal and women belonging to low socioeconomic groups are less likely to be screened (Dow et al. 2016), however other studies have also observed this association (Cosson et al. 2014). Discrepancies could be explained by the fact that some studies did not control for pre-pregnancy BMI and other potential confounding factors. Nevertheless, in additional sensitivity analysis excluding pre-pregnancy BMI from the multivariate model, women of Sub-Saharan descent were still not at increased risk of developing GDM.

\section{Alcohol and tobacco consumption}

Many immigrants originate from regions where women's levels of tobacco smoking and alcohol drinking are low (North and Sub-Saharan Africa) (Ng M et al. 2014), which could explain lower substance use levels in immigrants from these regions. Nevertheless, a convergence of smoking behaviours towards those of the host population is observed among descendants of immigrants (Bethel and Schenker 2005; Reeske et al. 2009). It appears that women progressively adopt the behavioural norms prevalent in the host country implicating that tobacco and alcohol use levels, which are high in France, need to be monitored in women born in France to foreign parents.

\section{Strengths and limitations}

This work is one of few European investigations analysing health behaviours in immigrant women and among descendants of immigrants in a large nationwide birth cohort study, with the possibility of adjusting for multiple covariates.

Nevertheless, we have to point out potential limitations. First, we were not able to measure immigrant women's acculturation. However, associations between immigrant status and each of the studied outcomes did not significantly change in sensitivity analyses adjusted for the duration of stay in France (supplementary tables). Second, another limitation is missing data concerning study outcomes. However, the percentage of missing data did not exceed $7.7 \%$, and it was 
highest in women who did not originate from the European Union. This may have led to an underestimation of the association between immigrant status and region of origin and studied outcomes. Another limitation is the exclusion of women not planning to stay in metropolitan France in the following three years, making our sample not-representative of all immigrant women giving birth in France at the time of recruitment. Classification bias is also possible, especially concerning non-immigrant women from the French oversea territories (women born French from French parents) who were classified as originating from "EU/France". This also might have also led to an underestimation of the association between immigrant status and studied outcomes.

\section{Conclusions}

Our results do not indicate a 'healthy immigrant effect', where immigrants are healthier than non-immigrants. They do however have some healthier behaviour than natives, especially concerning tobacco and alcohol consumption. Regarding overweight/obesity and GDM, immigrant women - particularly those from North and Sub-Saharan Africa - appear at elevated risk, as are women living in their country of origin.

Our findings point to complex relations between immigrant status and health behaviours and indicators during pregnancy, which are related to nativity as well as region of origin. These results suggest that immigrant women and descendants of immigrants who are pregnant need to benefit from medical follow-up which addresses their particular needs. Given the high proportion of births that occur among immigrant women, in terms of public health, strengthening existing positive health behaviours and preventing deleterious ones during pregnancy in this population can have a substantial population impact. 
Table 1: descriptive statistics of women participating in the ELFE (Etude Longitudinale Française Depuis l'Enfance) cohort (n=17,988, France, 2011) 


\begin{tabular}{|c|c|c|}
\hline \multicolumn{3}{|c|}{ Demographic characteristics (n. \%*) } \\
\hline & $<30$ years & $7724(42.9 \%)$ \\
\hline Age & $\geq 30$ years & $10134(56.3 \%)$ \\
\hline \multirow{2}{*}{ Number of children } & One & $8327(46.3 \%)$ \\
\hline & $\geq$ Two & $9661(53.7 \%)$ \\
\hline \multirow{8}{*}{ Residential area } & Paris & $3184(17.7 \%)$ \\
\hline & Paris region & $2699(15.0 \%)$ \\
\hline & North-Pas de Calais & $1411(7.8 \%)$ \\
\hline & East & $1592(8.9 \%)$ \\
\hline & West & $2282(12.7 \%)$ \\
\hline & South-West & $1300(7.2 \%)$ \\
\hline & Centre-East & $1784(9.9 \%)$ \\
\hline & Other & $1875(10.4 \%)$ \\
\hline \multicolumn{3}{|c|}{ Socioeconomic characteristics (n. \%*) } \\
\hline \multirow{4}{*}{ Occupational grade } & High & $3014(16.8 \%)$ \\
\hline & Intermediate & $4616(25.7 \%)$ \\
\hline & Low & $9056(50.3 \%)$ \\
\hline & No occupation & $1302(7.2 \%)$ \\
\hline \multirow{3}{*}{ Employment status } & Employed & $13929(77.4 \%)$ \\
\hline & Unemployed & $1017(5.7 \%)$ \\
\hline & Out of the job market & $2483(13.8 \%)$ \\
\hline \multirow{3}{*}{ Educational level } & $<$ High school degree & $3415(19.0 \%)$ \\
\hline & High school & $3760(20.9 \%)$ \\
\hline & $>$ High school degree & $10757(59.8 \%)$ \\
\hline \multicolumn{3}{|c|}{ Partner characteristics (n. \%*) } \\
\hline \multirow{2}{*}{ Smoking status } & Smoker & $4409(24.4 \%)$ \\
\hline & Non-smoker & $8089(44.9 \%)$ \\
\hline \multirow{3}{*}{$\begin{array}{c}\text { Partner's Employment } \\
\text { status }\end{array}$} & Employed & $15897(88.4 \%)$ \\
\hline & Unemployed & $835(4.6 \%)$ \\
\hline & Out of the job market & $618(3.4 \%)$ \\
\hline \multicolumn{3}{|c|}{ Pregnancy characteristics (n. \%*) } \\
\hline \multirow{2}{*}{ Unplanned pregnancy } & Yes & $2156(12.0 \%)$ \\
\hline & No & $15555(86.5 \%)$ \\
\hline \multirow{3}{*}{$\begin{array}{l}\text { Partner support during } \\
\text { pregnancy }\end{array}$} & Yes & $13517(74.1 \%)$ \\
\hline & No/insufficient & $1215(6.8 \%)$ \\
\hline & No partner & $978(5.4 \%)$ \\
\hline
\end{tabular}

*Missing values are included in the percentage calculation 
Table 2: Region of origin of immigrant women participating in the ELFE(Etude Longitudinale Française Depuis 1'Enfance) cohort study ( $\mathrm{n}=17,988$, France, 2011$)$

\begin{tabular}{|c|c|c|c|c|}
\hline Region of origin* & Non-immigrants & $\begin{array}{c}\text { Descendants of } \\
\text { immigrants }\end{array}$ & Immigrants & $\begin{array}{c}\text { Missing } \\
\text { value }\end{array}$ \\
\hline EU/France & $12294(100 \%)$ & $1064(53.2 \%)$ & $335(15.4 \%)$ & $\begin{array}{c}1407 \\
(92.9 \% \%)\end{array}$ \\
\hline North Africa, Turkey & - & $644(32.2 \%)$ & $807(37.0 \%)$ & $15(0.1 \%)$ \\
\hline Sub-Saharan Africa & - & $157(7.9 \%)$ & $561(25.8 \%)$ & $8(0.5 \%)$ \\
\hline Eastern Europe, Asia & - & $75(3.8 \%)$ & $225(10.3 \%)$ & $4(0.3 \%)$ \\
\hline Others, non-declared & - & $51(2.8 \%)$ & $239(11.0 \%)$ & $23(0.8 \%)$ \\
\hline \multicolumn{2}{|c|}{ Missing value } & $9(0.4 \%)$ & $12(0.8 \%)$ & $69(4.5 \%)$ \\
\hline
\end{tabular}

* Region of birth for immigrant women, and parents' region of birth for descendant of immigrants 
Table 3: Associations between women's immigrant status and region of origin with pre-pregnancy BMI and gestational diabetes mellitus (GDM) (multivariate multinomial and binomial logistic regression models, or; 95\% CI): the ELFE (Etude Longitudinale Française Depuis l'Enfance) birth cohort study, France, 2011. 


\begin{tabular}{|c|c|c|c|c|c|}
\hline \multirow{2}{*}{\multicolumn{2}{|c|}{ Variable* $^{*}$}} & \multicolumn{3}{|c|}{$\begin{array}{l}\text { Pre-pregnancy BMI (ref. normal) } \\
\qquad \mathrm{N}=17623\end{array}$} & \multirow[t]{2}{*}{$\begin{array}{c}\text { GDM } \\
\mathrm{N}=17045 \\
(\mathrm{ref}=\mathrm{No})\end{array}$} \\
\hline & & Underweight & Overweight & Obese & \\
\hline \multirow{3}{*}{$\begin{array}{c}\text { Immigrant } \\
\text { Status }\end{array}$} & Non-immigrants & 1 & 1 & 1 & 1 \\
\hline & $\begin{array}{l}\text { Descendants of } \\
\text { immigrants }\end{array}$ & $\begin{array}{c}0.96(0.77- \\
1.21)\end{array}$ & $\begin{array}{c}0.99(0.84- \\
1.16)\end{array}$ & $\begin{array}{c}0.96(0.78- \\
1.18)\end{array}$ & $\begin{array}{c}0.88(0.68- \\
1.14)\end{array}$ \\
\hline & Immigrants & $\begin{array}{c}0.78(0.57- \\
1.07)\end{array}$ & $\begin{array}{c}1.07(0.87- \\
1.32)\end{array}$ & $\begin{array}{c}0.83(0.63- \\
1.09)\end{array}$ & $\begin{array}{c}1.14(0.84- \\
1.56)\end{array}$ \\
\hline \multirow{5}{*}{$\begin{array}{l}\text { Region of } \\
\text { Origin }\end{array}$} & France/ EU & 1 & 1 & 1 & 1 \\
\hline & Eastern Europe, Asia & $\begin{array}{c}1.27(0.80- \\
2.01)\end{array}$ & $\begin{array}{c}0.59(0.39- \\
0.88)\end{array}$ & $\begin{array}{c}0.35(0.18- \\
0.69)\end{array}$ & $\begin{array}{c}2.00(1.27- \\
3.16)\end{array}$ \\
\hline & North Africa, Tukey & $\begin{array}{c}0.87(0.63- \\
1.20)\end{array}$ & $\begin{array}{c}1.39(1.13- \\
1.71)\end{array}$ & $\begin{array}{c}1.22(0.93- \\
1.59)\end{array}$ & $\begin{array}{c}1.68(1.25- \\
2.25)\end{array}$ \\
\hline & Sub-Saharan Africa & $\begin{array}{c}0.90(0.59- \\
1.37)\end{array}$ & $\begin{array}{c}1.37(1.06- \\
1.77)\end{array}$ & $\begin{array}{c}1.58(1.14- \\
2.18)\end{array}$ & $\begin{array}{c}1.11(0.76- \\
1.62)\end{array}$ \\
\hline & Others/ Non declared & $\begin{array}{c}1.07(0.65- \\
1.78)\end{array}$ & $\begin{array}{c}0.80(0.55- \\
1.15)\end{array}$ & $\begin{array}{c}1.02(0.64- \\
1.61)\end{array}$ & $\begin{array}{c}1.04(0.61- \\
1.76)\end{array}$ \\
\hline \multicolumn{6}{|c|}{ Demographic characteristics } \\
\hline \multirow[b]{2}{*}{ Mother's age } & $\geq 30$ years & 1 & 1 & 1 & 1 \\
\hline & $<30$ years & $\begin{array}{c}1.16(1.02- \\
1.32)\end{array}$ & $\begin{array}{c}0.98(0.90- \\
1.07)\end{array}$ & $\begin{array}{c}0.85(0.76- \\
0.96)\end{array}$ & $0.58(0.51-0.67)$ \\
\hline \multirow{3}{*}{$\begin{array}{c}\text { Educational } \\
\text { level }\end{array}$} & >High school & 1 & 1 & 1 & 1 \\
\hline & $<$ High school & $\begin{array}{c}1.32(1.12- \\
1.57)\end{array}$ & $\begin{array}{c}1.32(1.17- \\
1.49)\end{array}$ & $\begin{array}{c}1.82(1.58- \\
2.11)\end{array}$ & $1.01(0.85-1.21)$ \\
\hline & High school & $\begin{array}{c}0.97(0.82- \\
1.14)\end{array}$ & $\begin{array}{c}1.24(1.11- \\
1.38)\end{array}$ & $\begin{array}{c}1.36(1.18- \\
1.57)\end{array}$ & $0.94(0.80-1.11)$ \\
\hline \multirow{2}{*}{$\begin{array}{l}\text { Number of } \\
\text { children }\end{array}$} & $\geq 2$ & 1 & 1 & 1 & 1 \\
\hline & First & $\begin{array}{c}1.06(0.94- \\
1.19)\end{array}$ & $\begin{array}{c}0.80(0.74- \\
0.88)\end{array}$ & $\begin{array}{c}0.72(0.65- \\
0.81)\end{array}$ & $1.14(1.00-1.30)$ \\
\hline \multirow{6}{*}{$\begin{array}{l}\text { Residential } \\
\text { area }\end{array}$} & Ile de France & 1 & 1 & 1 & 1 \\
\hline & Paris Region & $\begin{array}{c}1.00(0.81- \\
1.23)\end{array}$ & $\begin{array}{c}1.04(0.90- \\
1.20)\end{array}$ & $\begin{array}{c}1.24(1.04- \\
1.47)\end{array}$ & $0.88(0.70-1.11)$ \\
\hline & Centre East & $\begin{array}{c}1.08(0.86- \\
1.35)\end{array}$ & $\begin{array}{c}0.95(0.80- \\
1.12)\end{array}$ & $\begin{array}{c}0.93(0.76- \\
1.15)\end{array}$ & $\begin{array}{c}0.97(0.75- \\
1.25)\end{array}$ \\
\hline & East & $\begin{array}{c}0.90(0.71- \\
1.15)\end{array}$ & $\begin{array}{c}0.97(0.82- \\
1.15)\end{array}$ & $\begin{array}{c}1.12(0.92- \\
1.37)\end{array}$ & $\begin{array}{c}0.91(0.69- \\
1.18)\end{array}$ \\
\hline & North-Pas de Calais & $\begin{array}{c}1.05(0.82- \\
1.35)\end{array}$ & $\begin{array}{c}1.09(0.92- \\
1.30)\end{array}$ & $\begin{array}{c}1.45(1.19- \\
1.78)\end{array}$ & $\begin{array}{c}1.06(0.81- \\
1.39)\end{array}$ \\
\hline & West & $\begin{array}{c}0.84(0.67- \\
1.05)\end{array}$ & $\begin{array}{c}0.98(0.84- \\
1.14)\end{array}$ & $\begin{array}{c}0.84(0.69- \\
1.03)\end{array}$ & $\begin{array}{c}0.99(0.78- \\
1.27)\end{array}$ \\
\hline
\end{tabular}




\begin{tabular}{|c|c|c|c|c|c|}
\hline & South-West & $\begin{array}{c}1.18(0.93- \\
1.50)\end{array}$ & $\begin{array}{c}0.76(0.63- \\
0.92)\end{array}$ & $\begin{array}{c}0.81(0.64- \\
1.03)\end{array}$ & $\begin{array}{c}0.97(0.75- \\
1.25)\end{array}$ \\
\hline & Other & $\begin{array}{c}1.13(0.91- \\
1.39)\end{array}$ & $\begin{array}{c}0.80(0.69- \\
0.94)\end{array}$ & $\begin{array}{c}0.72(0.58- \\
0.88)\end{array}$ & $\begin{array}{c}0.97(0.76- \\
1.23)\end{array}$ \\
\hline \multicolumn{6}{|c|}{ Socioeconomic characteristics } \\
\hline \multirow{4}{*}{$\begin{array}{l}\text { Occupational } \\
\text { grade }\end{array}$} & High & 1 & 1 & 1 & 1 \\
\hline & Intermediate & $\begin{array}{c}0.82(0.68- \\
0.98)\end{array}$ & $\begin{array}{c}1.55(1.34- \\
1.80)\end{array}$ & $\begin{array}{c}1.95(1.57- \\
2.43)\end{array}$ & $\begin{array}{c}0.98(0.80- \\
1.20)\end{array}$ \\
\hline & Low professional & $\begin{array}{c}0.97(0.81- \\
1.16)\end{array}$ & $\begin{array}{c}2.04(1.77- \\
2.36)\end{array}$ & $\begin{array}{c}2.93(2.37- \\
3.63)\end{array}$ & $\begin{array}{c}1.20(0.99- \\
1.46)\end{array}$ \\
\hline & No occupation & $\begin{array}{c}0.95(0.71- \\
1.28)\end{array}$ & $\begin{array}{c}1.68(1.34- \\
2.12)\end{array}$ & $\begin{array}{c}1.95(1.45- \\
2.63)\end{array}$ & $\begin{array}{c}1.25(0.91- \\
1.71)\end{array}$ \\
\hline \multirow{3}{*}{$\begin{array}{c}\text { Employment } \\
\text { status }\end{array}$} & Working & 1 & 1 & 1 & 1 \\
\hline & $\begin{array}{c}\text { Out of the job } \\
\text { market }\end{array}$ & $\begin{array}{c}1.39(1.15- \\
1.67)\end{array}$ & $\begin{array}{c}1.14(0.99- \\
1.31)\end{array}$ & $\begin{array}{c}1.71(1.47- \\
2.00)\end{array}$ & $\begin{array}{c}0.91(0.75- \\
1.11)\end{array}$ \\
\hline & Unemployed & $\begin{array}{c}1.17(0.92- \\
1.50)\end{array}$ & $\begin{array}{c}1.16(0.98- \\
1.38)\end{array}$ & $\begin{array}{c}1.45(1.19- \\
1.78)\end{array}$ & $\begin{array}{c}1.02(0.79- \\
1.31)\end{array}$ \\
\hline \multirow{3}{*}{$\begin{array}{c}\text { Educational } \\
\text { level }\end{array}$} & >High school & 1 & 1 & 1 & 1 \\
\hline & $<$ High school & $\begin{array}{c}1.32(1.12- \\
1.57)\end{array}$ & $\begin{array}{c}1.32(1.17- \\
1.49)\end{array}$ & $\begin{array}{c}1.82(1.58- \\
2.11)\end{array}$ & $\begin{array}{c}1.10(0.82- \\
1.49)\end{array}$ \\
\hline & High school & $\begin{array}{c}0.97(0.82- \\
1.14)\end{array}$ & $\begin{array}{c}1.24(1.11- \\
1.38)\end{array}$ & $\begin{array}{c}1.36(1.18- \\
1.57)\end{array}$ & $\begin{array}{c}1.09(0.84- \\
1.41)\end{array}$ \\
\hline \multicolumn{6}{|c|}{ Partner characteristics } \\
\hline \multirow{3}{*}{$\begin{array}{l}\text { Partner's } \\
\text { employment } \\
\text { status }\end{array}$} & Working & 1 & 1 & 1 & 1 \\
\hline & $\begin{array}{c}\text { Out of the job } \\
\text { market }\end{array}$ & $\begin{array}{c}1.76(1.37- \\
2.25)\end{array}$ & $\begin{array}{c}1.11(0.90- \\
1.39)\end{array}$ & $\begin{array}{c}1.31(1.02- \\
1.68)\end{array}$ & $\begin{array}{c}1.14(0.84- \\
1.54)\end{array}$ \\
\hline & Unemployed & $\begin{array}{c}1.38(1.07- \\
1.78)\end{array}$ & $\begin{array}{c}1.16(0.96- \\
1.39)\end{array}$ & $\begin{array}{c}1.48(1.20- \\
1.83)\end{array}$ & $\begin{array}{c}1.10(0.85- \\
1.44)\end{array}$ \\
\hline \multicolumn{6}{|c|}{ Health indicators } \\
\hline & Non-smokers & 1 & 1 & 1 & 1 \\
\hline Tobacco use & Before pregnancy & $\begin{array}{c}1.26(1.12- \\
1.42)\end{array}$ & $\begin{array}{c}0.88(0.81- \\
0.96)\end{array}$ & $\begin{array}{c}0.84(0.75- \\
0.93)\end{array}$ & $\begin{array}{c}1.02(0.87- \\
1.18) \\
1.03(0.88- \\
1.22)\end{array}$ \\
\hline \multicolumn{4}{|c|}{ Normal } & & 1 \\
\hline \multirow[b]{2}{*}{$\begin{array}{l}\text { BMI prior to } \\
\text { pregnancy }\end{array}$} & Underweight & & & & $\begin{array}{c}0.79(0.59- \\
1.07)\end{array}$ \\
\hline & Overweight & & & & $\begin{array}{c}2.25(1.94- \\
2.60)\end{array}$ \\
\hline
\end{tabular}




\begin{tabular}{|c|c|c|c|c|c|}
\hline \multicolumn{4}{|c|}{ Obese } & & $\begin{array}{c}4.12(3.52- \\
4.81)\end{array}$ \\
\hline \multicolumn{6}{|c|}{ Recruitment wave } \\
\hline \multirow{4}{*}{$\begin{array}{c}\text { Recruitment } \\
\text { wave }\end{array}$} & $\begin{array}{l}\text { November - } \\
\text { December }\end{array}$ & 1 & 1 & 1 & 1 \\
\hline & April & $\begin{array}{c}1.03(0.87- \\
1.23)\end{array}$ & $\begin{array}{c}0.92(0.81- \\
1.05)\end{array}$ & $\begin{array}{c}0.93(0.79- \\
1.10)\end{array}$ & $\begin{array}{c}0.78(0.64- \\
0.94)\end{array}$ \\
\hline & June-July & $\begin{array}{c}1.03(0.88- \\
1.20)\end{array}$ & $\begin{array}{c}0.94(0.84- \\
1.04)\end{array}$ & $\begin{array}{c}0.96(0.83- \\
1.10)\end{array}$ & $\begin{array}{c}0.85(0.73- \\
1.00)\end{array}$ \\
\hline & September-Oc-ber & $\begin{array}{c}1.02(0.88- \\
1.18)\end{array}$ & $\begin{array}{c}0.95(0.86- \\
1.06)\end{array}$ & $\begin{array}{c}1.12(0.99- \\
1.28)\end{array}$ & $\begin{array}{c}0.93(0.80- \\
1.08)\end{array}$ \\
\hline
\end{tabular}

*All covariates are presented in grey 
Table 4: Associations between women's immigrant status and region of origin with alcohol and tobacco consumption during pregnancy (multivariate multinomial logistic regression models, OR; 95\% CI): ELFE (Etude Longitudinale Française Depuis l'Enfance) birth cohort study, France, 2011. 


\begin{tabular}{|c|c|c|c|c|c|}
\hline \multirow[t]{2}{*}{ Variable* } & & \multicolumn{2}{|c|}{$\begin{array}{l}\text { Tobacco use during pregnancy } \\
\text { (ref. non-smokers) } \\
\mathrm{N}=17,746\end{array}$} & \multicolumn{2}{|c|}{$\begin{array}{l}\text { Alcohol use during } \\
\text { pregnancy (ref. never } \\
\text { drank) } \mathrm{N}=\mathbf{1 7 , 8 3 8}\end{array}$} \\
\hline & & $\begin{array}{l}\text { Quit during } \\
\text { pregnancy }\end{array}$ & Smokers & $\begin{array}{c}<\text { once per } \\
\text { month }\end{array}$ & $\begin{array}{c}\geq \text { once per } \\
\text { month }\end{array}$ \\
\hline \multirow{3}{*}{$\begin{array}{c}\text { Immigrant } \\
\text { Status }\end{array}$} & Non-immigrants & 1 & 1 & 1 & 1 \\
\hline & $\begin{array}{l}\text { Descendants of } \\
\text { immigrants }\end{array}$ & $1.11(0.96-1.29)$ & $\begin{array}{c}1.01(0.85- \\
1.21)\end{array}$ & $\begin{array}{c}0.79(0.66- \\
0.94)\end{array}$ & $\begin{array}{c}0.97(0.71- \\
1.31)\end{array}$ \\
\hline & Immigrants & $0.48(0.38-0.60)$ & $\begin{array}{c}0.34(0.26- \\
0.45)\end{array}$ & $\begin{array}{c}1.05(0.82- \\
1.35)\end{array}$ & $\begin{array}{c}1.47(0.99- \\
2.18)\end{array}$ \\
\hline \multirow{5}{*}{$\begin{array}{l}\text { Region of } \\
\text { Origin }\end{array}$} & France/ EU & 1 & 1 & 1 & 1 \\
\hline & $\begin{array}{c}\text { Eastern Europe } \\
\text { Asia }\end{array}$ & $0.58(0.39-0.86)$ & $\begin{array}{c}0.68(0.42- \\
1.10)\end{array}$ & $\begin{array}{l}0.83(0.55- \\
1.24)\end{array}$ & $\begin{array}{c}0.72(0.36- \\
1.45)\end{array}$ \\
\hline & North Africa, Tukey & $0.33(0.26-0.42)$ & $\begin{array}{c}0.49(0.38- \\
0.64)\end{array}$ & $\begin{array}{l}0.13(0.09- \\
0.21)\end{array}$ & $\begin{array}{l}0.19(0.10- \\
0.35)\end{array}$ \\
\hline & Sub-Saharan Africa & $0.31(0.22-0.43)$ & $\begin{array}{l}0.28(0.19- \\
0.41)\end{array}$ & $\begin{array}{c}1.06(0.77- \\
1.44)\end{array}$ & $\begin{array}{c}1.12(0.68- \\
1.84)\end{array}$ \\
\hline & $\begin{array}{c}\text { Others/ Non } \\
\text { declared }\end{array}$ & $0.70(0.48-1.02)$ & $\begin{array}{c}0.43(0.25- \\
0.74)\end{array}$ & $\begin{array}{c}1.09(0.73- \\
1.63)\end{array}$ & $\begin{array}{l}1.90(1.10- \\
3.31)\end{array}$ \\
\hline \multicolumn{6}{|c|}{ Demographic characteristics } \\
\hline \multirow[b]{2}{*}{ Mother's age } & $\geq 30$ years & 1 & 1 & 1 & 1 \\
\hline & $<30$ years & $0.80(0.73-0.88)$ & $\begin{array}{c}0.90(0.81- \\
0.99)\end{array}$ & $\begin{array}{l}0.69(0.62- \\
0.76)\end{array}$ & $\begin{array}{c}0.54(0.44- \\
0.66)\end{array}$ \\
\hline \multirow[b]{2}{*}{$\begin{array}{l}\text { Number of } \\
\text { children }\end{array}$} & $\geq 2$ & 1 & 1 & 1 & 1 \\
\hline & first & $1.20(1.11-1.31)$ & $\begin{array}{c}1.13(1.03- \\
1.25)\end{array}$ & $\begin{array}{l}0.84(0.76- \\
0.92)\end{array}$ & $\begin{array}{c}0.69(0.58- \\
0.82)\end{array}$ \\
\hline \multirow{8}{*}{$\begin{array}{l}\text { Residential } \\
\text { area }\end{array}$} & Ile de France & 1 & 1 & 1 & 1 \\
\hline & Paris Region & $1.15(0.97-1.36)$ & $\begin{array}{c}1.01(0.85- \\
1.21)\end{array}$ & $\begin{array}{c}1.01(0.85- \\
1.19)\end{array}$ & $\begin{array}{c}0.9(0.67- \\
1.22)\end{array}$ \\
\hline & Centre East & $1.16(0.95-1.41)$ & $\begin{array}{c}1.13(0.93- \\
1.38)\end{array}$ & $\begin{array}{l}0.86(0.71- \\
1.05)\end{array}$ & $\begin{array}{c}0.8(0.56- \\
1.14)\end{array}$ \\
\hline & East & $1.01(0.82-1.24)$ & $\begin{array}{c}1.22(0.99- \\
1.49)\end{array}$ & $\begin{array}{c}0.87(0.71- \\
1.07)\end{array}$ & $\begin{array}{c}0.67(0.46- \\
0.98)\end{array}$ \\
\hline & North-Pas de Calais & $0.99(0.80-1.24)$ & $\begin{array}{c}0.90(0.73- \\
1.12)\end{array}$ & $\begin{array}{c}0.50(0.39- \\
0.64)\end{array}$ & $\begin{array}{l}0.42(0.27- \\
0.67)\end{array}$ \\
\hline & West & $1.25(1.04-1.50)$ & $\begin{array}{c}1.30(1.08- \\
1.56)\end{array}$ & $\begin{array}{c}0.93(0.78- \\
1.11)\end{array}$ & $\begin{array}{c}0.97(0.71- \\
1.33)\end{array}$ \\
\hline & South-West & $1.34(1.08-1.66)$ & $\begin{array}{c}1.20(0.97- \\
1.49)\end{array}$ & $\begin{array}{l}0.97(0.79- \\
1.20)\end{array}$ & $\begin{array}{c}0.94(0.64- \\
1.36)\end{array}$ \\
\hline & Other & $1.28(1.06-1.54)$ & $\begin{array}{c}1.26(1.05- \\
1.53)\end{array}$ & $\begin{array}{c}0.73(0.60- \\
0.88)\end{array}$ & $\begin{array}{c}0.96(0.7 \text { - } \\
1.33)\end{array}$ \\
\hline
\end{tabular}


Socioeconomic characteristics

\begin{tabular}{|c|c|c|c|c|c|}
\hline \multirow{4}{*}{$\begin{array}{c}\text { Occupational } \\
\text { grade }\end{array}$} & High & 1 & 1 & 1 & 1 \\
\hline & Intermediate & $0.96(0.85-1.07)$ & $\begin{array}{c}1.24(1.05- \\
1.47)\end{array}$ & $\begin{array}{c}0.75(0.66- \\
0.85)\end{array}$ & $\begin{array}{c}0.65(0.52- \\
0.82)\end{array}$ \\
\hline & Low professional & $1.08(0.96-1.22)$ & $\begin{array}{c}1.70(1.43- \\
2.01)\end{array}$ & $\begin{array}{c}0.66(0.58- \\
0.76)\end{array}$ & $\begin{array}{c}0.51(0.41- \\
0.65)\end{array}$ \\
\hline & No occupation & $0.69(0.54-0.90)$ & $\begin{array}{c}1.15(0.87- \\
1.51)\end{array}$ & $\begin{array}{c}0.48(0.36- \\
0.66)\end{array}$ & $\begin{array}{c}0.40(0.25- \\
0.67)\end{array}$ \\
\hline \multirow{3}{*}{$\begin{array}{c}\text { Employment } \\
\text { status }\end{array}$} & Working & 1 & 1 & 1 & 1 \\
\hline & $\begin{array}{l}\text { Out of the job } \\
\text { market }\end{array}$ & $0.89(0.77-1.03)$ & $\begin{array}{c}1.18(1.02- \\
1.37)\end{array}$ & $\begin{array}{c}0.90(0.76- \\
1.07)\end{array}$ & $\begin{array}{c}1.15(0.87- \\
1.52)\end{array}$ \\
\hline & Unemployed & $1.18(0.99-1.41)$ & $\begin{array}{c}1.46(1.20- \\
1.77)\end{array}$ & $\begin{array}{c}1.03(0.84- \\
1.27)\end{array}$ & $\begin{array}{c}1.15(0.81- \\
1.65)\end{array}$ \\
\hline \multirow{3}{*}{$\begin{array}{c}\text { Educational } \\
\text { level }\end{array}$} & >High school & 1 & 1 & 1 & 1 \\
\hline & $<$ High school & $1.30(1.15-1.48)$ & $\begin{array}{c}2.75(2.39- \\
3.15)\end{array}$ & $\begin{array}{c}0.66(0.57- \\
0.77)\end{array}$ & $\begin{array}{c}0.77(0.59- \\
1.01)\end{array}$ \\
\hline & High school & $1.17(1.05-1.31)$ & $\begin{array}{c}1.93(1.70- \\
2.18)\end{array}$ & $\begin{array}{c}0.78(0.69- \\
0.89)\end{array}$ & $\begin{array}{c}0.77(0.60- \\
0.99)\end{array}$ \\
\hline \multicolumn{6}{|c|}{ Partner characteristics } \\
\hline \multirow{3}{*}{$\begin{array}{l}\text { Partner's } \\
\text { employment } \\
\text { status }\end{array}$} & Working & 1 & 1 & 1 & 1 \\
\hline & $\begin{array}{c}\text { Out of the job } \\
\text { market }\end{array}$ & $0.93(0.74-1.18)$ & $\begin{array}{c}1.01(0.81- \\
1.28)\end{array}$ & $\begin{array}{c}0.78(0.58- \\
1.05)\end{array}$ & $\begin{array}{c}1.01(0.63- \\
1.63)\end{array}$ \\
\hline & Unemployed & $0.87(0.70-1.08)$ & $\begin{array}{c}1.1(0.90- \\
1.35)\end{array}$ & $\begin{array}{c}0.67(0.51- \\
0.88)\end{array}$ & $\begin{array}{c}0.85(0.55- \\
1.32)\end{array}$ \\
\hline \multirow{2}{*}{$\begin{array}{l}\text { Partner's } \\
\text { tobacco use }\end{array}$} & Non-smokers & 1 & 1 & 1 & 1 \\
\hline & Smokers & $1.98(1.78-2.20)$ & $\begin{array}{c}6.5(5.78- \\
7.31)\end{array}$ & $\begin{array}{c}1.08(0.95- \\
1.24)\end{array}$ & $\begin{array}{c}1.04(0.82- \\
1.31)\end{array}$ \\
\hline \multicolumn{6}{|c|}{ Pregnancy characteristics } \\
\hline \multirow[b]{2}{*}{$\begin{array}{l}\text { Unplanned } \\
\text { pregnancy }\end{array}$} & No & 1 & 1 & 1 & 1 \\
\hline & Yes & $1.02(0.90-1.17)$ & $\begin{array}{c}1.64(1.44- \\
1.86)\end{array}$ & $\begin{array}{c}1.26(1.10- \\
1.45)\end{array}$ & $\begin{array}{c}1.17(0.92- \\
1.50)\end{array}$ \\
\hline \multirow[t]{3}{*}{$\begin{array}{l}\text { Support } \\
\text { during } \\
\text { pregnancy }\end{array}$} & Well surrounded & 1 & 1 & 1 & 1 \\
\hline & No/ seldom & $0.99(0.85-1.16)$ & $\begin{array}{c}1.31(1.11- \\
1.54)\end{array}$ & $\begin{array}{c}1.19(1.01- \\
1.40)\end{array}$ & $\begin{array}{c}1.43(1.08- \\
1.88)\end{array}$ \\
\hline & Not in a couple & $0.87(0.70-1.07)$ & $\begin{array}{c}1.49(1.21- \\
1.85)\end{array}$ & $\begin{array}{c}1.01(0.81- \\
1.26)\end{array}$ & $\begin{array}{c}1.05(0.73- \\
1.52)\end{array}$ \\
\hline
\end{tabular}




\begin{tabular}{|c|c|c|c|c|c|}
\hline \multirow{2}{*}{$\begin{array}{l}\text { Tobacco use } \\
\text { during } \\
\text { pregnancy }\end{array}$} & \multicolumn{3}{|l|}{ Former smoker } & $\begin{array}{c}1.36(1.22- \\
1.52)\end{array}$ & $\begin{array}{c}1.62(1.33- \\
1.99)\end{array}$ \\
\hline & Smoker & & & $\begin{array}{c}1.64(1.43- \\
1.87)\end{array}$ & $\begin{array}{c}3.00(2.40- \\
3.76)\end{array}$ \\
\hline \multirow{3}{*}{$\begin{array}{l}\text { Alcohol use } \\
\text { during } \\
\text { pregnancy }\end{array}$} & No & 1 & 1 & & \\
\hline & $<$ Once per month & $1.35(1.21-1.51)$ & $\begin{array}{c}1.64(1.44- \\
1.88)\end{array}$ & & \\
\hline & $\geq$ Once per month & $1.62(1.32-1.99)$ & $\begin{array}{c}3.04(2.44- \\
3.81)\end{array}$ & & \\
\hline \multicolumn{6}{|c|}{ Recruitment wave } \\
\hline \multirow{4}{*}{$\begin{array}{l}\text { Recruitment } \\
\text { wave } \\
\text { (ref=Novembe } \\
\text { r-December) }\end{array}$} & $\begin{array}{l}\text { November - } \\
\text { December }\end{array}$ & 1 & 1 & 1 & 1 \\
\hline & April & $0.96(0.86-1.06)$ & $\begin{array}{c}0.89(0.79- \\
1.01)\end{array}$ & $\begin{array}{c}0.97(0.86- \\
1.10)\end{array}$ & $\begin{array}{c}1.17(0.94- \\
1.45)\end{array}$ \\
\hline & June-July & $0.92(0.84-1.02)$ & $\begin{array}{c}0.91(0.81- \\
1.02)\end{array}$ & $\begin{array}{c}0.93(0.83- \\
1.05)\end{array}$ & $\begin{array}{c}1.15(0.93- \\
1.41)\end{array}$ \\
\hline & September-October & $0.93(0.82-1.05)$ & $\begin{array}{c}0.90(0.78- \\
1.03)\end{array}$ & $\begin{array}{c}1.10(0.96- \\
1.25)\end{array}$ & $\begin{array}{rr}\text { 7. } & 0.83- \\
1.38)\end{array}$ \\
\hline
\end{tabular}

*All covariates are presented in grey 


\section{Ethical approval:}

All procedures performed in studies involving human participants were in accordance with the ethical standards of the institutional and/or national research committee and with the 1964 Helsinki declaration and its later amendments or comparable ethical standards.

The ELFE study received approval from France's consultative committee for the treatment for health information for research (CCTIRS) and the national data protection authority (CNIL).

Informed consent: Informed consent was obtained from all individual participants included in the study.

\section{REFERENCES}

Agrawal A, Scherrer JF, Grant JD, et al (2010) The effects of maternal smoking during pregnancy on offspring outcomes. Prev Med 50:13-18. doi: 10.1016/j.ypmed.2009.12.009

Almeida LM, Caldas J, Ayres-de-Campos D, et al (2013) Maternal Healthcare in Migrants: A Systematic Review. Matern Child Health J 17:1346-1354. doi: 10.1007/s10995-012-1149-x

Barker DJ (2012) Sir Richard Doll Lecture. Developmental origins of chronic disease. Public Health 126:185-9. doi: 10.1016/j.puhe.2011.11.014

Beauchemin C, Hamel C, Simon P, Héran F (eds) (2015) Trajectoires et origines: enquête sur la diversité des populations en France. Ined ditions, Paris

Bethel JW, Schenker MB (2005) Acculturation and Smoking Patterns Among Hispanics: A Review. Am J Prev Med 29:143-148. doi: 10.1016/j.amepre.2005.04.014

Cosson E, Cussac-Pillegand C, Benbara A, et al (2014) The Diagnostic and Prognostic Performance of a Selective Screening Strategy for Gestational Diabetes Mellitus According to Ethnicity in Europe. J Clin Endocrinol Metab 99:996-1005. doi: 10.1210/jc.2013-3383

Crowther CA, Hiller JE, Moss JR, et al (2005) Effect of Treatment of Gestational Diabetes Mellitus on Pregnancy Outcomes. N Engl J Med 352:2477-2486. doi: 10.1056/NEJMoa042973

DAVIES A, Basten A, Frattini C (2009) Migration: A Social Determinant of the Health of Migrants. International Organization for Migration, Geneva, Switzerland

Delavari M, Sønderlund AL, Swinburn B, et al (2013) Acculturation and obesity among migrant populations in high income countries - a systematic review. BMC Public Health 13:458. doi: $10.1186 / 1471-2458-13-458$

Dow C, Fosse-Edorh S, Perrine A, et al (2016) CA-107: Dépistage, prévalence et pronostic du diabète gestationnel en France en 2011 : l'étude ELFE. Diabetes Metab 42:A64. doi: 10.1016/ S1262-3636(16)30239-7

Europ-Peristat (2013) The European Perinatal Health Report. The health and care of pregnant women and babies in Europe in 2010

Eurostat (2017) Migration and migrant population statistics

Falah-Hassani K, Shiri R, Vigod S, Dennis C-L (2015) Prevalence of postpartum depression among immigrant women: A systematic review and meta-analysis. J Psychiatr Res 70:67-82. doi: 10.1016/j.jpsychires. 2015.08.010 
Gagnon AJ, McDermott S, Rigol-Chachamovich J, et al (2011) International migration and gestational diabetes mellitus: a systematic review of the literature and meta-analysis. Paediatr Perinat Epidemiol 25:575592. doi: 10.1111/j.1365-3016.2011.01230.x

Gagnon AJ, Zimbeck M, Zeitlin J (2010) Migration and perinatal health surveillance: An international Delphi survey. Eur J Obstet Gynecol Reprod Biol 149:37-43. doi: 10.1016/j.ejogrb.2009.12.002

Gilbert PA, Khokhar S (2008) Changing dietary habits of ethnic groups in Europe and implications for health. Nutr Rev 66:203-215. doi: 10.1111/j.1753-4887.2008.00025.x

Guardia D, Salleron J, Roelandt J-L, Vaiva G Prévalence des troubles psychiatriques et addictologiques auprès de trois générations successives de migrants : résultats d'une étude menée en population générale. L'Encéphale. doi: 10.1016/j.encep.2016.06.008

Khlat M, Guillot M (2017) Health and Mortality Patterns Among Migrants in France. Popul Cent Work Pap PSCPARC

Kulu H, González-Ferrer A (2014) Family Dynamics Among Immigrants and Their Descendants in Europe: Current Research and Opportunities. Eur J Popul 30:411-435. doi: 10.1007/s10680-014-9322-0

Kulu H, Hannemann T, Pailhé A, et al (2017) Fertility by Birth Order among the Descendants of Immigrants in Selected European Countries. Popul Dev Rev 43:31-60. doi: 10.1111/padr.12037

Mårdby A-C, Lupattelli A, Hensing G, Nordeng H (2017) Consumption of alcohol during pregnancy-A multinational European study. Women Birth. doi: 10.1016/j.wombi.2017.01.003

McEwen BS, Gianaros PJ (2010) Central role of the brain in stress and adaptation: Links to socioeconomic status, health, and disease. Ann N Y Acad Sci 1186:190-222. doi: 10.1111/j.1749-6632.2009.05331.x

Melchior M, Chollet A, Glangeaud-Freudenthal N, et al (2015) Tobacco and alcohol use in pregnancy in France: The role of migrant status: The nationally representative ELFE study. Addict Behav 51:65-71. doi: 10.1016/j.addbeh.2015.07.015

Metzger BE (2007) Long-term Outcomes in Mothers Diagnosed With Gestational Diabetes Mellitus and Their Offspring: Clin Obstet Gynecol 50:972-979. doi: 10.1097/GRF.0b013e31815a61d6

Missinne S, Bracke P (2012) Depressive symptoms among immigrants and ethnic minorities: a population based study in 23 European countries. Soc Psychiatry Psychiatr Epidemiol 47:97-109. doi: 10.1007/ s00127-010-0321-0

Moullan Y, Jusot F (2014) Why is the 'healthy immigrant effect' different between European countries? Eur J Public Health 24:80-86. doi: 10.1093/eurpub/cku112

Ng M, Freeman MK, Fleming TD, et al (2014) Smoking prevalence and cigarette consumption in 187 countries, 1980-2012. JAMA 311:183-192. doi: 10.1001/jama.2013.284692

OECD (2014) Foreign-born unemployment

OECD Centre for Opportunity and Equality (2017) Understanding the socio-economic divide in Europe

OECD, UN-DESA (2013) World Migration in Figures

Rechel B (2011) Migration and Health in the European Union. McGraw-Hill Education (UK)

Rechel B, Mladovsky P, Ingleby D, et al (2013) Migration and health in an increasingly diverse Europe. The Lancet 381:1235-1245. doi: 10.1016/S0140-6736(12)62086-8

Reeske A, Spallek J, Razum O (2009) Changes in smoking prevalence among first- and second-generation Turkish migrants in Germany - an analysis of the 2005 Microcensus. Int J Equity Health 8:26. doi: $10.1186 / 1475-9276-8-26$ 
Saurel-Cubizolles M-J, Saucedo M, Drewniak N, et al (2012) Santé périnatale des femmes étrangères en France. Bull Épidémiologique Hebd 2:3-4

Vandentorren S, Bois C, Pirus C, et al (2009) Rationales, design and recruitment for the Elfe longitudinal study. BMC Pediatr 9:58. doi: 10.1186/1471-2431-9-58

Williams JF, Smith VC, Abuse the COS (2015) Fetal Alcohol Spectrum Disorders. Pediatrics 136:e1395e1406. doi: 10.1542/peds.2015-3113 